\title{
What Do Theatre Autobiographies Conceal?
}

\section{RIKARD HOOGLAND}

\begin{abstract}
Autobiographies by actors and directors are considered to be somewhat of an unreliable source of information where research on theatre history is concerned. Researchers have made a great deal of effort to validate facts in autobiographies, but then have often neglected other forms of information that the written source gives. In this article, four different autobiographies are analysed with a specific focus on autobiographical strategies (Gardner), the embodied act of writing (Schneider), hegemonic processes in society (Bratton), and audiences (Singleton). The article discusses if it is possible to place autobiographies in both the repertoire and the archive in Taylor's sense, and if they can be seen as a possible link between them.
\end{abstract}

\section{KEYWORDS}

Repertoire, archive, autobiography, embodiment, self-representation, Ranft. 


\section{What Do Theatre Autobiographies Conceal?}

Historical research should be built upon evidence and sources that have gone through a process of validation. Easy to say, but much harder to carry out in practice. Researchers are often happier about findings and not so often about questioning the selection process behind the material they have found, a selection process that a researcher is not really in control of. What could be done is to expand the sources to include material that has not been seen as reliable by researchers. In this example, I will look into cases from four different autobiographies. In three of the cases, the same incidents are described. The fourth example gives a different view of the main character of the cases, the successful Swedish theatre manager Albert Ranft. I will also take into consideration theatre historiographical writings about autobiographies and diaries. In what way could autobiographies be used in theatre history writing? Could they be used beyond being an uncertain source material? Do they give hidden information about their writers and the surrounding theatrical field?

The three autobiographical writers are quite different, one a theatre manager, one an impresario and the third an actor. None of the autobiographies are written in cooperation with a second writer, or seem to have a ghost-writer. All of the books are written at the end of the respective authors' careers and, for each of them, it is a natural way to place themselves in the history of theatre and mark their own importance. In order for the books to be published, it was first of all important that the person was still well known so there could be enough interested readers. The second thing that must have been of importance was the choice of histories told. For instance, are they interesting enough to trigger the fantasy of the reader? This could lead to the writer exaggerating an episode in order to tell a good story. There is also the question of memory as a natural selection process. Archives are often described as our collective memory. But what do the archives cover and what do they not? The aim of this study is to see if there are other ways to analyse autobiographies and how useful they then could be when writing theatre history. The first section of the article discusses different theories, strategies, and studies concerning sources, archives, and autobiographies. Especially central for the article are Diana Taylor's notions about the archive and the repertoire. In the second part, these theories are applied to the selected autobiographies. 


\section{THE ARCHIVE AND THE REPERTOIRE}

Dianna Taylor, in her book from 2003, supplements the archive with what she calls the repertoire. She argues against the use of the dichotomy between written and oral sources, it is too much of a constructed difference:

\footnotetext{
The rift, I submit, does not lie between the written and spoken world, but between the archive of supposedly enduring materials (i.e., texts, documents, buildings, bones) and the so-called ephemeral repertoire of embodied practice/knowledge (i.e., spoken language, dance, sports, ritual). ${ }^{1}$
}

The archive is a construction and not an objective source, it is made up of the material which has been "selected, classified, and presented for analysis." The material could, during its time, have been changed due to political manipulation, continues Taylor. The repertoire, too, goes through changes:

\footnotetext{
This means that the repertoire, like the archive, is mediated. The process of selection, memorization or internalization, and transmission takes place within (and in turn helps constitute) specific systems of re-presentation. Multiple forms of embodied acts are always present, though in a constant state of againness. ${ }^{3}$
}

Another problem with the archive is the ownership of the archive and the institution/theatres that have produced and collected the material. There is a clear difference between state owned companies and private enterprises (who often have been closed down or gone through bankruptcies.) The archival sources need, in my opinion, to be completed with other material. Diana Taylor, however, raises a warning, "our theoretical tolls continue to be haunted by the literary legacy." Here, I could add that a researcher is also haunted by the canon, no matter how hard we try to oppose it. When writing a history based on other significant events than those that have been highlighted by the canon of the modern breakthrough, striving to find false accounts in earlier findings could be too demanding a task when selecting examples.

\section{REBECCA SCHNEIDER'S CRITIQUE}

In her book, Performing Remains: Art and War in Times of Theatrical Re-enactment, Rebecca Schneider criticizes Diana Taylor's analysis of the relationship between the repertoire (embodied and disappearing) and the archive (written and preserved sources). Even though Taylor tries (as mentioned earlier) to avoid seeing the relationship as a dichotomy, she fails in Schneider's view:

Taylor does not entirely succeed, in other words, in resisting the binary archive/ performance. [...] Taylor realigns a distinction between the two and asserts a
1. Taylor 2003, 19.
2. Taylor 2003, 19.
3. Taylor 2003, 21.
4. Taylor 2003, 27. 
linear trajectory: as if writing were not an embodied act, nor an embodied encounter across time, and as if performance were not discursive (nor discourse performative or 'performatic'). ${ }^{5}$

Schneider points out that "both writing and performance are reiterative, and both take place live and in cross-temporal negotiation." 6 More than just criticizing Taylor's view, Schneider succeeds in complementing it. The writing process is an act of embodiment that also works as a cross-temporal-negotiation. When it comes to biographies and autobiographies, I would argue that several time layers are employed simultaneously during the writing process. During the writing process, the body memory is employed in a process to memorize acting, reactions and feelings. I would argue that at the same time the author performs his memory, he is attempting to construct how he should be remembered. Autobiographies can be seen as both a part of the archive and the repertoire by the way they simultaneously work within several layers of temporality - the time when the event occurred, the time when the book was written and published, and the time when it is read.

\section{AUTOBIOGRAPHIES AS SOURCE MATERIAL}

Autobiographies have mostly been valued as something that can act as a complementary source. Thomas Postlewait points out that the autobiographer writes for two audiences, the inner circle (family and colleagues) and the general public. "The writer tries to shape the story of a life, to inform, please, convince, counter, and control both audiences."

Postlewait emphasizes the usefulness of autobiographies in research besides obtaining evidence. The biographies "not only help to negotiate the place and status of theatre people within society but also serve to sanction, reinforce, and justify the operation of theatre entertainment as a vital component of the social order." 8 Postlewait demands that autobiographies should not only be seen as documentary material, but also as performing pieces. The writer has an underlying self-promoting agenda and shapes the person that is presented for the readers. All "autobiographies [...] offer imaginative constructions of both a character and a narrative voice."

The notion of performing links Postlewait's description to Diana Taylor's term repertoire and Rebecca Schneider's critical development of it. Autobiographies can be seen as objects that can be placed both in the archive and in the repertoire. They are a personal description of a time passed and clearly subjective. However, it is of specific interest that Schneider also sees the process of writing as an act of embodiment. The autobiographies make it possible

5. Schneider 2011, 107.

6. Schneider 2011, 107.

7. Postlewait 1989, 258.

8. Postlewait 2000, 158.

9. Postlewait 2000, 165. 
to get in contact with the writers performed embodiment. I would also argue that not only the act of writing is an act of embodiment, the writers' self-presentation could also be analysed as such. Sidonie Smith and Julia Watson write, in their book, about autobiographies that "People tell stories of their lives through the cultural scripts available to them, and they are governed by cultural strictures about self-presentation in public."10 One narrative that was dominant during this period was the "representative life of the great man". ${ }^{11}$

Lena Hammergren, in her book about dance and historiography, states that opinions given in an autobiography are no truer than those given in reviews (which are often used as an important source). ${ }^{12}$ I would add, however, that the time difference between the occasion and the comment is so much longer in an autobiography than in a review. This could lead to a more honest description in a memoir, but, on the other hand, shouldn't the writer consider other views which could adjust the memory of the occasion? Furthermore, is there a selective memory in play that changes the story? It all depends on which source material the writers have at hand besides their own memory, how they choose to perform it and for which audience.

Jacky Bratton, in her study New Readings in Theatre History, asks questions about how theatre researchers (mis)use autobiographies as a source. Or, to be more exact, do not use all the possibilities that could be employed in research. "[T]hey have not often been read for what their writers or their subjects seem to stress, or what their contemporary readership might have understood of theatre history from them."13 She also studies the difference between autobiographies written by men and women. Men seem to see themselves as independent and central, whereas women place themselves in relation to others, "a sense of identification, interdependence and community is key in the development of women's identity and therefore also central in their stories of themselves." ${ }^{14}$

To conclude this section, Bratton shows the need to read autobiographies in relation to the hegemonic process in society with regard to gender, class, and the status of theatre. Her work has been inspiring for researchers into female playwrights and actors during the 19th century. Viv Gardner, amongst them, finds that the autobiography could "offer an opportunity to consider the ways in which the performer/writer employ self-representation, 'autobiographical strategies', to reposition herself in the hierarchies and histories of the theatre." 15

Lena Hammergren has analyzed the historical writings on Isadora Duncan. They contrast, for instance, Duncan's view on serious and popular culture with

\footnotetext{
10. Smith, Watson 2010, 235.

11. Smith, Watson 2010, 196.

12. Hammergren 2009.

13. Bratton 2003, 95.

14. Bratton 2003, 101-102.

15. Gardner 2005, 4.
} 
the contemporary view on Afro-American culture and Jazz. This gives a perspective of Duncan as not being in tune with her time. ${ }^{16}$

This also leads to a question of writing strategies in the selection process: how should the autobiographer write about successful events that at the time of publication have lost their value? Viv Gardner's notion about autobiographical strategies could, here, come in use, in which way are the writers promoting themselves in the writing process. When it comes to temporality it is important, as Jacky Bratton emphasises to look at the contemporary hegemonic processes in society and performing arts in combination with the biographies.

\section{SELECTION PROCESSES BEFORE PUBLICATION}

A question that arises is: how usual were (auto)biographies in Sweden during the period before the Second World War? There is no concise overview of the Swedish market of publications during the period. Looking at the Christmas of 1928 when Albert Ranft's autobiography was published, an advertisement from a bookseller in Stockholm lists 12 new biographies and autobiographies. The only other theatrical autobiography was the famous actor Gösta Ekman's Den tänkande August. ${ }^{17}$ For a theatre researcher it is notable that very few directors and actors were the object of autobiographies or biographies. Several famous actors and directors never had any biography or autobiography published. One important attempt was a series of short biographies that was published in 1918/19 under the title "The Favourites of the Audience", but the series only ran to eight small volumes. ${ }^{18}$ The interest for information about theatre personalities was perhaps fulfilled by theatre magazines, gossip journals, and interviews in the daily papers. However, some of the most popular artists (such as Gösta Ekman, Naima Wifstrand, Pauline Brunius) did have several books published by or about them. The Swedish market was probably too small to accommodate a large amount of biographies from the field of the performing arts. The different theatre magazines were often also short-lived; public interest was just not large enough. ${ }^{19}$

\section{RANFT'S APOLOGY}

Albert Ranft dominated the Swedish theatre system between 1890 and 1925 . As a private theatre manager, he succeeded in building up a gigantic theatrical enterprise, running several theatres in Stockholm, one in Gothenburg and two touring companies. During a short while, he also undertook responsibility for the Royal Opera House. He was criticized for his dominant position, that he engaged the best actors, and for having a repertoire consisting of plays marked by immorality or low, spectacular quality. In defence against these accusations he published a book called Min repertoar (My repertoire) where he listed all

\footnotetext{
16. Hammergren 2009, 93-96.

17. Advertisement Dagens Nyheter 1928.

18. In Swedish "Publikens gunstlingar"

19. Janzon 1975.
} 
the plays and dramatists that he had produced on his stages in Stockholm. ${ }^{20}$ He had to fight in a two front war; he was attacked by the daily paper Svenska morgonbladet, a religious newspaper allied to the Free Church movement and, on the other front, the directors that saw theatre as a high art form. The two fronts were morality and art, on the first front, he was too modern, while on the other, he was accused of being too old-fashioned. The outbreak started with a production of Mikhail Artsybashev's Svartsjuka (Jealousy), which premiered at Svenska Teatern on 23rd March 1921. The play was accused of promoting sexual relations outside marriage and also of being of low quality.

Svenska morgonbladet, in several articles, reported on the low quality of the production and its questionable morality based on an investigation undertaken by a parson about the nightlife in Stockholm. The 6th April headline was "Albert Ranft - a front man for theatre decadence". ${ }^{21}$ The attack and the investigation were reported on in several other daily papers and these were often not in support of Ranft. At the same time, he was also criticized for being too much of a businessman and that his repertoire could not be considered as high art. After being criticized even for the way he answered his attackers, Ranft decided to produce a more elaborate apologia.

It had certainly a very personal form. The title declares that it is his personal repertoire. This implies that every decision on the repertoire has been his personal choice. In his own analysis of the repertoire, he makes a concluding statement in order to mark the difference: "[...]l have chosen my repertoire of my own free will and without being bound to any duties put on me because I have not received any support, governmental or private whatsoever." 22 Here, he stands forward as an independent self-made man not responsible for anyone else other than his audience and employees. He seems to be very secure in his position, not letting us know anything about the economic problems that his company was undergoing. He does, however, emphasize that he has not received any governmental support, which is a clear stand against both Lorensbergsteatern and the Royal Dramatic Theatre. He even uses Strindberg and his defence in court in 1884 when accused of defeating the Christian Church, and he uses Strindberg's expression "entrepreneurs in ethics". ${ }^{23}$ In this way, he positions himself on the same level as the national author. Shakespeare, too, is called upon as defender for Ranft: "had not Shakespeare's name been on The Tempest, several of the lines that are articulated during the burlesque scenes would have been accused of immorality by the ethical zealots". ${ }^{24} \mathrm{He}$ closes his introduction with the thought that he now, with confidence, awaits the judgement of public opinion. What the book does not cover is the other critical voices that questioned the artistic quality of his productions; amongst them, the director Per Lindberg and the daily newspaper Dagens Nyheter. Ranft probably

\footnotetext{
20. Ranft 1921.

21. S.n. Svenska morgonbladet 6 April 1921.

22. Ranft 1921, 96.

23. Ranft 1921, 6.

24. Ranft 1921, 11.
} 
found that in the public view, a fight against the Free Church movement was an easier task to answer than the question of artistic quality. However, his notion about being independent from private and public funding is a way to indirectly comment on the critique. He also bases his defence on the plays' and the writers' origins. It seems to be important for him to emphasize that a great deal of the plays were written by Swedish authors. He could also have mentioned the directors and beloved actors, but, for some unclear reason, he neglects to do so. It is also interesting to note that several critics discussed if Gunnar Klintberg's staging underlined the immorality of the play Svartsjuka (Jealousy)..$^{25}$ Ranft's retort to this is that many critics immediately see immorality if a bed is on stage or mentioned in a play.

\section{PROFESSIONAL AUTOBIOGRAPHY}

This is not a typical autobiography, it is a sort of professional biography in which Ranft takes full responsibility for his theatres. He writes in the first person and never talks of we at the theatre. This very assertive response is made to convince the readers. Ranft's choice of basing his defence on the plays and the playwrights instead of the acting and staging can be understood as his acceptance of the notion of the time that theatrical playing was subordinate to literary texts. His position in the selection process is central, it is not the directors, actors, advisers nor the leaders of the companies that have any responsibility for the repertoire. He admits no mistakes during his process of compiling the repertoire, nor does he go into which considerations he made during the selection of, for example, the ensemble or plays of international reputation. At his theatres, plays by Strindberg, Ibsen, Wilde, Schnitzler, and Hauptmann had their Swedish premieres, but the majority of his productions were operettas, comedies, and revues. Ranft was one of the first theatre managers who named the director on the billboard, but he seems not to be supportive of the new directing styles that were emerging during the time when the book was published. Ranft was much more interested in building an ensemble and engaging actors that were recognised by a broad audience. In the writing process of self-presentation that could be seen as an act of embodiment, the central person of the defence text stands alone, confident that he is a bearer of quality and moral based on solid literary taste. The way he stands out in the book is part of a strategy for convincing the readers and critics. But his autobiographical strategy to stand up as a singular strong person could also open for a weakness when he does not construct a strong defence group behind him. Here, he uses a strategy that would be seen as a strength in the business sector, but as a weakness in the theatre world when underlining the fact that he had been running the company with economic success instead of pointing out the artistic choices he had made. The apology has a performative quality and can be seen as a part of the repertoire in Taylor's/Schneider's sense.

Ranft's problem with his apology was, in a way, his choice of listing the

25. e.g. Smith Svenska Dagbladet 23 March 1921. 
repertoire on all his stages in Stockholm, including more popular theatre forms and not only the stages that were meant for, what he calls, "high drama". The director, Per Lindberg, commented on Ranft's book in the theatre journal Scenen and concluded that "during thirty years, nine Shakespeare productions compared with twenty Algot Sandberg, twenty one Emil Nordlander and more than thirty bedroom farces." ${ }^{26}$ Ranft responded in one of the Stockholm newspapers claiming that Lindberg did not know anything about building a repertoire or running a theatre with a stable economy. "You think that everything is as it should be if a small group of modernists applaud some of the so called new when it comes to decorations.[...] with an ideal to estrange from healthy nature and pure real art as much as possible."27

Ranft gives the impression of being an omnipotent theatre manager with a high literary taste, full of financial confidence. However, when he chooses to base his defence on his selection of plays, he notes that he does not really approve of the new theatre trends such as the elevation of the director in a central position for the artistic theatre. Lindberg also takes a risk in his accusations against Ranft: Lorensbergsteatern under Lindberg had financial problems and the theatre did not only produce high art productions.

Brian Singleton has studied the British theatre manager Oscar Asche and his use of orientalism. Asche seems to have a lot in common with Ranft. They both built theatre enterprises that produced highly acclaimed high art plays and combined them with productions of entertainments and spectacular plays. Singleton found that by giving his own narrative of the scandals and "his own version of this theatrical past, Asche was not simply offering a present perspective and discourse on his lived past. He was also providing what Ricoeur, in his analysis of the methods and aims of historical narrative, calls an 'emplotment between a stage of practical experience that precedes it and a stage that succeeds it'." ${ }^{28}$ The strategies of their apologies seem similar, but they both failed when one contemplates how they have been validated in theatre history.

\section{ALBERT RANFT AND THE ANECDOTES}

In 1928, after his company had undergone several bankruptcies and he was no longer regarded as the great "theatre king" he once was, his autobiography was published. ${ }^{29}$ It covers the time from when he attended his first theatre performance at the age of eight (1864) until he bought Svenska teatern in 1898.

This means that he could barely cover the foundational years of his theatre enterprise as it was only once he'd succeeded in buying Svenska teatern that Ranft really started to build up a larger enterprise. The front page declares that this is the first volume, but no second volume followed. It is unclear if it was the publishing company or Ranft himself that lost interest. In press reports there

\footnotetext{
26. Lindberg Scenen 16/1921, 248.

27. Ranft Svenska Dagbladet 19 October 1921.

28. Singleton 2010, 366 .

29. Ranft 1928.
} 
was talk about several volumes. One reason could be the lack of commercial interest. Less than six years after publication, the volume was put on sale for one Swedish Crown as opposed to the original price of six Crowns. ${ }^{30}$

Ranft's autobiography has been used as source material for various theatre history writings, but it is hard to clarify how useful and truthful it is. It is mostly a collection of anecdotes presented in chronological order that give us some information about Ranft's relation to competing theatre managers, authors, actors, and critics.

The difference between Ranft's professional autobiography (the apology) from 1921 and this book published in 1928 is that the latter is a personal autobiography that allows the reader to come closer to the author. ${ }^{31}$ Or, to be more exact, the reader should feel he/she has a personal relationship with the author. The former "king of theatre" now tries to create the memory of his achievements as a theatre developer. He was still active as actor, director, and theatre organizer, but not at all on the same grand scale as earlier. Besides establishing his place and importance in theatrical history, Ranft's autobiography also had the task of presenting amusing stories so the book would be of interest for potential buyers. However, how reliable are the stories and in what light is he presented in them? Was it important for the readers, or were they content just being amused?

One important story is how he dared to successfully stage a play by Gustaf af Geijerstam, Andras affärer (Others' business), in Gothenburg in 1894 despite it having been a huge failure at Dramaten in Stockholm. When the summer repertoire opened at Djurgårdsteatern in Stockholm he was advised by a theatre critic not to put it on the bill. It was, however, a huge success even in Stockholm, probably due to a stronger ensemble. The episode shows Ranft as a man who had a good nose for success and who dared to take decisions that could have put his company in critical circumstances if they failed. He can also be seen as a gambler. The way the story is told by Ranft may seduce the readers into taking his side. The ensemble thinks that the rehearsals in Gothenburg will be stopped when the failure in Stockholm becomes clear, but they are surprised when they are called in for a new round of rehearsals. Ranft notes, "The success was total, and by that we showed what can be achieved with a correct view and energetic work." 32 Less fruitful repertoire decisions are not given any importance in the story, it would only have disturbed the main point if he had taken them into consideration. One important task for the writer, Ranft, is to put forward Albert Ranft's interest for and knowledge about theatre and not let the economic success dominate the narrative. Per Lindberg, as mentioned be-

30. Advertisement, Dagens Nyheter 15 April 1934.

31. The only attempt to write a biography about Ranft is 76 pages of a never finalized biography written by Arthur Wieland found in the archive of the Municipal museum in Gothenburg. Wieland s.a., Göteborgs stadsmuseum, Teatersamlingarna, Albert Ranfts arkiv 1.

32. Ranft 1928, 139. 
fore, and others had accused him of being an unscrupulous theatre merchant only interested in making as much money as possible. Ranft thus needed to tell a story about a man devoted to plays and producing theatre. The positive economical outcome is only fortuitous in that it gives Ranft the possibility to produce even more theatre to satisfy the demands of the audience.

The dominant part (two-thirds) of the book covers the period before he started his own company. As a historical record, the book is sometimes very detailed. For example, its lists of actors in a specific production; at other times the book is superficial. To flavour the story, Ranft includes memories of dinners and a couple of meetings with King Oscar II, who had wanted to give the Royal Dramatic Theatre to him. When these are not enough, he recounts amusing stories with minor relevance to the main narrative.

The story begins during his childhood when his interest for theatre began to grow into an obsession and how he and his elder brother, Gustaf, tried hard to get money for theatre tickets. His theatre interest leads to an engagement in a touring theatre company with a rather strange manager. The feeling I get when reading the book is that I am sharing a restaurant table with Albert who tells story after story from his rich theatrical life. Underneath, however, there is a frame to the narrative. On one of the first pages he tells of how, as a child, he visited the construction site of Nya Teatern almost every day. The book ends with how he buys the same theatre now named Svenska Teatern. Here, it is clear that even though the book can be described as a collection of anecdotes, Ranft still succeeds in giving it a main narrative. It builds a frame that begins with how he discovers the theatre as a child and sees how it is constructed, and ends up with him taking command of the most important stage in Stockholm. It visualises the history of the self-made man who, all his life, has been occupied with building up a successful theatre enterprise. The different anecdotes are in this way subordinate to the main narrative.

I will now give two examples of occasions that he describes and compare them with two different sources: the actor Justus Hagman's and the impresario Gustave Thalberg's autobiographies.

\section{JUSTUS HAGMAN'S AUTOBIOGRAPHY}

Hagman was an important actor for Albert Ranft. For over 20 years he played the dwarf, Didrik, in the fairy tale play, Ljungby horn. He probably played the part over 400 times. For some years, he was also responsible for Ranft's Östermalmsteatern with a mixture of operettas, popular theatre, and adventure plays. Thereafter, he was tour leader for Ranft's dramatic ensemble. In his autobiography he treats Ranft with great respect and diminishes his own role. There is not a word of criticism against Ranft and it seems that he, as actor, looked up to him with great respect. Hagman's book was published in 1922, the year after the strong critique of the immorality and low quality of Ranft's repertoire. Hagman comments on the criticism and calls it nonsense, but ad- 
mits that "high art" often means that the audience chooses to stay at home. ${ }^{33}$ It can be seen as an act of support that Hagman does not in any way criticize Ranft.

In Hagman's autobiography, he tells the story of how Albert Ranft's older brother, Gustaf, disrupted the technical works on stage when preparing for the production of Ljungby horn's move in 1894 to Stockholm when the tour was in Malmö. Through a practical joke, Gustaf Ranft was deluded into going to a meeting in a neighbouring town so he no longer could disrupt the technical works. The episode is also presented in Ranft's autobiography, but in a slightly different way. ${ }^{34}$ Ranft's version was published six years after Hagman's and it is likely that Ranft partly reused the story. Ranft diminishes his part in the joke and changes some parts so the invitation to the meeting comes by telephone instead of by letter, and it happens when the production was being prepared for the period in Malmö.

It could be said to be an anecdote of minor interest, but it tells us something about the relationships within the theatre company and Albert's relation to his older brother. Justus Hagman recounts a helpful relationship between Albert and Gustaf. For example, Albert warns him of the possibility that the invitation could be made up. In the description, Gustaf and Albert are not mentioned by name; instead he calls them "Brother Director" and "Big brother". In this version, Gustaf listens to Albert's advice, phones the theatre, asks about the time of the meeting, and then realizes that it was all a set up. Afterwards, he was occupied with finding the person guilty of carrying out the joke.

In Albert Ranft's own description, he is not at all active in the joke and does not give Gustaf any warning. He even makes fun of Gustaf's reaction when he realizes that he has been exposed to a joke. In this version, Gustaf leaves for the non-existent meeting and comes back the day after not admitting anything. The use of the telephone instead of letter tells us that he is eager to stand forward as a man of modernity. Another difference in the two books is that Gustaf Ranft is a part of Albert's book right from the beginning, so the relationship between the two brothers can be followed through the years.

The character, Albert Ranft, is portrayed in two different forms. In Hagman's, as a person who is helpful to his older brother, while in Ranft's own description, as a person who only observes and is not at all disgruntled to see his older brother get a telling off.

Ranft employed actors from both his own family and his wife's. It is proof of how Ranft's company was in the middle of the transition from a family based touring company to a professional theatre enterprise. The story can be seen as reliable when it occurs in two different books, but it could also be a case of rewriting and reusing. Theatre anecdotes are important for keeping the theatre community together and they live their own transforming life. The anecdotes can be seen as a part of the repertoire in Taylor's sense, as an oral tradition

33. Hagman 1922, 122.

34. Hagman 1922, 113-115; Ranft 1928, 141-143. 
which, through the process of publication, is fixed in print. Through the two stories, it is possible to obtain information about the status between the family members as well as between the actors and Albert Ranft. This is information that cannot be gleaned in other documents and could be an important complement to the archive.

Hagman's autobiography seems to be more spontaneously written, ignoring a lot of important parts of his career and choosing, instead, to write about others. He also relates facts that have been used in theatre history writing, but often these "facts" have not gone through any validation. The reuse of facts that have been found to be uncertain in writing theatre history is a problem, as Postlewait pointed out. ${ }^{35}$ For the writer of autobiographies it is not a problem as they often want to strengthen their narrative. Therefore, the borrowing of anecdotes, details and situations can be a successful strategy. It can be seen as performing a part of the repertoire by the process of writing. Of importance is that the two men apply completely different methods when it comes to autobiographical strategies in Viv Gardner's sense. For Albert Ranft, it is still of great importance to be a self-promoter, while Hagman plays down his own role.

\section{TWO IBSEN-STORIES}

In two autobiographies, a meeting with the playwright Henrik Ibsen is recounted. Reading them side by side gives the impression that a lot of details are similar. One of the stories is told by Albert Ranft, the other by Gustave Thalberg. Thalberg's book from 1906 Bland "stjärnor". En svensk impresarios erindringar (Amongst 'stars'. A Swedish impresario's memoirs) begins with a dedication to President Roosevelt, which places Thalberg firmly on an international stage. ${ }^{36}$ Thalberg recounts tours with opera singers, musicians, explorers, authors, and comedians. The stories are geographically spread in Mexico, the USA, Russia, and Sweden. One chapter is called "An Ibsen story" and is about how he, in the Grand Hotel in Kristiania (Oslo), has an unarranged meeting with Ibsen and tries to engage him for a lecture tour in the USA. ${ }^{37}$

In Ranft's description, he has written to Ibsen and asked for the Swedish rights of the play Little Eyolf before it was published and staged in Kristiania. The answer to the letter was not helpful, so he travels to Kristiania and the Grand Hotel to have a meeting, if possible. In both stories, the authors use a waiter to gain information, they both approach Ibsen when he is sitting reading a newspaper, and they drink "pjolter", which Ibsen offers. In Thalberg's case, it is seen as something remarkable that Ibsen invites someone for a drink. Furthermore, Thalberg writes that everyone at the hotel talked about the occasion for days afterwards. In Ranft's case, it is true that he gained the rights for the first Swedish production of the play, but we don't know if there ever was any meeting between Ranft and Ibsen. Can it be that Ranft, when writing his au-

35. Postlewait 2000, 165.

36. Thalberg 1906.

37. Thalberg 1906, 297-306. 
tobiography, used some of the colours from Thalberg's autobiography? Or is it the case that neither Ranft nor Thalberg ever met Ibsen at the Grand Hotel? Ranft cooperated with Thalberg directly after his book was published in 1906, so it is highly likely that Ranft received a copy of the book. ${ }^{38}$

When looking into the information about Little Eyolf in the digital Ibsen archive at the Norwegian National Library, the records tell us that the play had its first premiere in London in December of 1894, while the Norwegian premiere was on 15th January, 1895. There was even a production in Swedish before Ranft's at the Swedish Theatre in Helsinki on 21st January, while Ranft's production had its first night in Gothenburg on 30th January, $1895 .{ }^{39}$ It was, of course, remarkable that a touring company in Sweden gained the rights to produce a new lbsen play. Preserved in the lbsen archive is also a draft contract between Ibsen and Ranft concerning the exclusive right to produce the play in Sweden during the following two years, but no correspondence about the case is preserved. ${ }^{40}$

Here, too, we see two different ways of portraying the main character of the autobiography. Thalberg presents himself as an adventurer who takes chances and always held many possibilities open. At the same time he was planning a tour with the wife of the missing explorer Fritjof Nansen and he wanted to complement it with a more exclusive tour with Ibsen. Ranft wants things to happen, so when the playwright does not answer in a proper way by letter, he goes on rather a long trip to Kristiania without any real preparations. Here, Ranft places himself in a discourse of modernity, with fast communications that make such unplanned movements possible, and having commerce with one of the writers that opened up for modernity on stage. When talking with lbsen, a lot of funny misunderstandings occur, but Ranft cleverly navigates around them. For both Thalberg and Ranft it is of importance to emphasize that Ibsen was friendly toward them and recognized them. In both cases, they break common social rules when approaching lbsen directly, but by navigating cleverly, they succeed. For Ranft, the meeting with Ibsen is of importance because it proves his connection to the canonised literary world. Thalberg presents himself as an adventurer, whereas Ranft presents himself as a man of strategic thinking.

\section{CONCLUSIONS}

The autobiographies that I have referred to here were written during a time when the conditions for theatre were in a state of change. The professionalization of acting and directing had increased. The division between popular and

38. Ranft used Thalberg to negotiate with Gordon Craig who organized Isadora Duncan's guest performance at Ranft's Östermalmsteatern, s. n. Dagens Nyheter 12 March 1906.

39. Ibsen, 1895 Lille Eyolf, Repertoardatabasen, Alt om Henrik Ibsen, Norges Nasjonalbiblioteket.

40. Ibsen 1894 (?), Utkast til kontrakt med teaterdirektør A[lbert] R[anft] for oppførelsen i Sverige av Lille Eyolf, Alt om Henrik Ibsen, Norges Nasjonalbiblioteket. 
serious, high art theatre had been enforced. The subsidy system for theatre had evolved and demands were made for a further development of it. The movie industry was changing ordinary people's entertainment habits in the growing cities. Entertainment taxes and legislation against liquor altered the possibility of earning money in the performing arts.

The three autobiography authors Ranft, Hagman, and Thalberg began their careers when the transition had already started. They had gone through a period when it was possible to make a lot of money out of theatre. Financial and political crisis and epidemics in society had, naturally, also interfered with the possibility of maintaining a large private theatre landscape.

Both Postlewait and Singelton write about the narrative voice, which the writer performs in an autobiography. Which character stands out from the written pages? As Postlewait concludes, it is an imaginative construction. This also interferes with the selection process of events that are covered in the book. Viv Gardner calls the process that makes a person more central and important "autobiographical strategies". The author chooses episodes that could still be of interest in contemporary (theatre) society and where s/he is placed in a central position with regard to them. This can be seen as part of the construction of what Smith and Watson call the narrative about the great man.

Jacky Bratton argues that we, as researchers, need to look more at what the writer was trying to emphasize and how contemporary readers interpreted it. I think that this has to be combined with a double gaze both at the past and how the past has been transmitted over the years. It is interesting to see the choices that the authors have made. Why does Justus Hagman write so little about himself and instead talk about others? This form of choice probably says a lot about the person behind the autobiography. Ranft plays two very different roles in his two books. On the one hand, the very self-confident theatre king who chooses which plays to produce with certainty and literary taste. In this case, it is important to note that he defends himself on the grounds of the literary quality of the repertoire and that the number of Swedish playwrights in the repertoire is a mark of its high standard. On the other hand, when it comes to his memoirs from the beginnings of his theatrical enterprise, we meet a person who tries a lot of different things and through his theatrical innovativeness prevails. Ranft is in the first book presented as a self-confident business entrepreneur and in the later (the memoire) as an experimental inventor. Thalberg likes to present himself as an explorer who uses half-truths in order to achieve success. Hagman chooses to stand forward as an ordinary worker and a passive observer instead of presenting himself as a successful actor and theatre manager. In their methods of self-presentation, they have confidently selected different performative appearances in the text.

Singleton notes that other than the author's goal of establishing a form of self-justification and importance, there is "a desire to remember the past in specific ways that enhance the supposedly unique qualities of the lost era." ${ }^{\prime 11}$

41. Singelton, 366. 
This is something that I would say dominates the examples given here. But of importance are the values during the time the book was written, as Hammergren's example shows with Isadora Duncan's relation to popular culture.

Taylor divides the sources between the repertoire and the archive. Furthermore, she is also of the opinion that the literary legacy could well be the predominant factor when it comes to the archive. In Rebecca Schneider's criticism, she finds that Taylor, in her description of the two sources, emphasises the difference too strongly. She argues that writing is an embodied act and that the repertoire works in conjunction with discursive and cross-temporal practises. Schneider questions Taylor's division of the archive and the repertoire by defining parts of the archival sources as not only literary but also performative objects. These, too, can be placed in the repertoire.

In my opinion, autobiographies are not the archive nor are they the repertoire. Autobiographies can be traces of evidence, but they open up to performative aspects that bring the material alive. Autobiographies can, in that way, act as a link between the repertoire and the archive, and broaden our understanding of theatre history.

\section{References}

Advertisement. Dagens Nyheter 1 December 1928.

Advertisement. Dagens Nyheter 15 April 1934.

Bratton, Jacky 2003. New Readings in Theatre History. Cambridge: Cambridge University Press.

Gardner, Viv 2005. "Documents of performance. 'Diary of an actress': an introduction." Nineteenth Century Theatre and Film 32:1.

Hagman, Justus 1922. På scenen och bakom. Stockholm: Seelig \& Co.

Hammergren, Lena 2009. Dans och historiografiska reflektioner. Stockholm: STUTS.

Janzon. Leif 1975. Teatertidskrifter i Sverige: 1900-1940, Teatervetenskapliga småskrifter 11, STUTS: Stockholm.

Lindberg, Per 1921. "Albert Ranfts pjäskatalog", Scenen, 16.

Postlewait, Thomas 1989. "Autobiography and Theatre History". In Thomas Postlewait \& Bruce A. McConachie (eds.). Interpreting the Theatrical Past: Essays in the Historiography of Performance. lowa City: University of lowa Press.

Postlewait, Thomas. 2000. "Theatre Autobiographies: Some Preliminary Concerns for the Historian", Assap C 16. 
Ranft, Albert 1921. Min repertoar 1892-1921, Stockholm.

Ranft, Albert 1921. "Tjäna pengar på teater är stor konst anser Ranft". Svenska Dagbladet 19 October.

Ranft, Albert 1928. Albert Ranfts memoarer, första delen. Stockholm: Norstedts.

Schneider, Rebecca 2011. Performing Remains: Art and War in Times of Theatrical Reenactment. London \& New York: Routledge.

Singleton, Brian 2010. "Narratives of nostalgia. Oriental evasions about the London stage". In Charlotte M. Canning \& Thomas Postlewait (eds.). Representing the Past. Essays in Performance Historiography. lowa City: University of lowa Press.

Smith, Ejnar 1921. "Ryskt på Svenska Teatern." Svenska Dagbladet 21 March.

Smith, Sidonie \& Watson, Julia 2010. Reading Autobiography: A Guide for Interpreting Life Narratives. second edition. Minneapolis: University of Minnesota Press.

s.n. 1921. "Albert Ranft - banerföraren för teaterdekadansen." Svenska morgonbladet 6 April.

s.n. 1906. "Kommer till Stockholm." Dagens Nyheter 12 March.

Taylor, Diana 2003. The Archive and the Repertoire: Performing Cultural Memory in the Americas. Durham/London: Duke University Press.

Thalberg, Gustave 1906. Bland 'stjärnorna'. En svensk impresarios erindringar. Från artistlif, resor och äfventyr i främmande länder. Stockholm.

Arthur, Wieland, s.a., "Teaterkungen Albert Ranft", manuscript, Göteborgs stadsmuseum, Teatersamlingarna, Albert Ranfts arkiv 1.

\section{AUTHOR}

Rikard Hoogland is senior lecturer in Theatre studies at Stockholm University. $\mathrm{He}$ received his $\mathrm{PhD}$ in 2005. He also teaches the subject Cultural Policy. He has published in peer reviewed journals - Perepeti, the Nordic Journal of Culture Policy - and in anthologies published by Cambridge Scholars, Cambridge University Press, Ohlms, Palgrave, and Rodopi. He has been a visiting scholar at Freie Universität, Berlin. He is also part of the research project Turning Points and Continuity: The Changing Roles of Performance in Society 18801925, financed by the Swedish Research Council.

rikard.hoogland@teater.su.se 